\title{
STUDI HUKUM KELUARGA ISLAM DI TUNISIA
}

\section{Mochammad Agus Rachmatulloh}

Fakultas Syariah IAIN Kediri

magusr@iainkediri.ac.id

\begin{abstract}
The phenomenon of "assimilation" between Islamic law and positive law in Muslim countries, such as the legalization of Islamic law as a national law, has often occurred in Muslim countries that have long implemented the western legal system. The reform of Islamic family law in Muslim countries has continued to develop starting from the early 20th century, and Tunisa is one of them. Legal reform in Tunisia cannot be separated from the historical aspect behind it. The role of education and nationalist fighters as agents of reform is also decisive. The process of formulating and structuring Islamic family law in Tunisia, is not only an effort to codify the Maliki and Hanafi schools of figh and the presence of French influence, but also to take progressive and revolutionary steps in an effort to legalize and regulatory in the field of law, with the birth of Majallat al- Ahwal al-Syakhshiyah or the Tunisian Code of Personal Status (CPST). The attitude of the Tunisian state towards legal reform is generally included in the group of countries that carry out legal reform in a democratic manner to suit the demands and developments of the times in accordance with the contemporary context. The nature of the method used in the family law reform still refers to the concept of conventional figh (intra doctrinal reform) in synergy with the legacy of French law in order to reinterpret the texts (extra doctrinal reform). The legal reforms carried out by Tunisia, did not intend to deviate and abandon the principles of Islamic law, but rather caused by the government's desire to guarantee the welfare, peace and benefit of the Tunisian nation and people.
\end{abstract}

\section{Keywords: Family Law, Islam, Tunisia}

ABSTRAK: Fenomena "asimilasi" antara hukum Islam dan hukum positif di negara-negara muslim, seperti dilegislasikannya hukum Islam sebagai hukum nasional, banyak terjadi di negara-negara muslim yang telah lama menerapkan sistem hukum barat. Pembaharuan hukum keluarga Islam di negara-negara muslim terus berkembang dimulai dari awal abad ke-20, dan Tunisa merupakan salah satu diantaranya. Pembaharuan hukum di Tunisia tidak terlepas dari aspek historis yang melatarbelakanginya. Peran pendidikan 
dan pejuang nasionalis sebagai pelaku pembaharuan juga ikut menentukan. Proses perumusan dan penataan hukum keluarga Islam di Tunisia, tidak hanya sekedar upaya kodifikasi fikih mazhab Maliki maupun Hanafi serta adanya pengaruh Prancis, akan tetapi juga melakukan langkah-langkah progresif dan revolusioner dalam upaya melakukan legalisasi dan regulatory dalam bidang hukum, dengan lahirnya Majallat al-Ahwal al-Syakhshiyah atau Code of Personal Status Tunisia (CPST). Sikap negara Tunisia terhadap pembaharuan hukum secara umum masuk dalam kelompok negara yang melakukan pembaharuan hukum secara demokrat untuk disesuaikan dengan tuntutan dan perkembangan zaman sesuai dengan konteks kontemporer. Sifat metode yang digunakan dalam pembaharuan hukum keluarga tetap merujuk pada konsep fiqih konvensional (intra doctrinal reform) dengan disinergikan dengan warisan hukum Prancis guna melakukan reinterpretasi pada nash (ekstra doctrinal reform). Reformasi hukum yang dilakukan Tunisia, tidak bermaksud untuk melakukan penyimpangan dan meninggalkan prinsip-prinsip hukum Islam, akan tetapi lebih disebabkan keinginan pemerintah untuk menjamin kesejahteraan, kedamaian, dan kemaslahatan bangsa negara dan rakyat Tunisia.

\section{Kata Kunci: Hukum Keluarga, Islam, Tunisia}

\section{PENDAHULUAN}

Hukum mengatur tingkah laku atau tindakan manusia dalam masyarakat. Peraturan berisikan perintah dan larangan untuk melakukan sesuatu atau tidak melakukan sesuatu. Hal ini dimaksudkan untuk mengatur perilaku manusia agar tidak bersinggungan dan merugikan kepentingan umum.

Sebagai makhluk sosial, manusia tidak akan bisa hidup tanpa ada hukum yang mengatur pergaulan hidup mereka. Setiap persekutuan manusia, baik modern atau primitif, membutuhkan hukum untuk mengatur hidup mereka agar aman dan tertib. Tidak dapat dibayangkan bagaimana persekutuan atau suatu kelompok manusia tanpa hukum yang mengatur tata kehidupan. ${ }^{1}$

Hukum yang paling awal dikenal manusia adalah hukum keluarga, khususnya hukum perkawinan. Seiring dengan perkembangan zaman, hukum keluarga Islam juga mengalami banyak perubahan dan pembaharuan.

1 Muhammad Amin Suma, Hukum Keluarga Islam di Dunia Islam (Jakarta: Raja Grafindo Persada, 2004), 2. 
Banyaknya sistem hukum yang berlaku pada masing-masing negara, mengindikasikan kemajemukan masyarakat dunia pada satu pihak, dan pluralisme hukum yang berlaku di pihak lain. Bahkan tidak jarang dalam satu negara atau masyarakat hukum, berlaku sistem hukum yang berbeda. Di negara-negara yang penduduknya tergolong heterogen, berlaku hukum yang pluralis memang merupakan sesuatu yang tidak bisa dielakkan.

Sama halnya dengan sistem hukum lain yang berlaku di belahan bumi yang berbeda-beda, sistem hukum keluarga Islam masih tetap eksis dan terus berlaku di dunia Islam. Dari sekian banyak negara Islam, baik negara berpenduduk mayoritas Muslim maupun berpenduduk muslim minoritas sekalipun, hukum keluarga Islam benar-benar menjadi hukum yang hidup (living law) dan diamalkan oleh keluarga-keluarga Muslim. ${ }^{2}$

Saat ini terdapat fenomena "asimilasi" antara hukum Islam dan hukum positif di negara-negara muslim. Seperti dilegilasikannya hukum Islam sebagai hukum nasional, fenomena ini banyak terjadi di negara-negara muslim, yang telah lama menerapkan sistem hukum barat. Aspirasi untuk menerapkan hukum Islam sebagai hukum nasional sangat kuat, sehingga dengan strategi legilasi materi hukum Islam dalam bentuk legal drafting menjadi RUU untuk ditetapkan sebagai hukum perundang-undangan dapat terjadi.

Pembaharuan hukum keluarga Islam di negara-negara muslim teruslah berkembang dimulai dari awal abad ke-20, terutama terkait perkawinan, perceraian dan kewarisan. Usaha ini dimulai oleh Turki (1917), kemudian Libanon (1919), Mesir (1920 dan 1929), Yordania (1951), Syiria (1953) dan Tunisia adalah salah satu negara muslim yang mengalami fenomena ini pada tahun 1956.

Usaha pembaharuan ini memiliki beberapa tujuan, diantaranya (1) unifikasi hukum keluarga, (2) peningkatan status wanita, dan (3) merespon perkembangan zaman karena konsep fikih klasik dianggap belum mampu menjawabnya. ${ }^{3}$

2 Muhammad Amin Suma, Hukum Keluarga Islam di Dunia Islam (Jakarta: Raja Grafindo Persada, 2004), 9.

3 Khoiruddin Nasution, Status Wanita di Asia Tenggara: Studi terhadap Perundangundangan Perkawinan Muslim Kontemporer di Indonesia dan Malaysia (Jakarta: INIS, 2002), 45. 
Pasca-kolonial, Tunisia melaksanakan law reform, dengan membuat hukum Islam dengan birokrasi modern. Islamic law reform ini terutama dimulai dari wilayah hukum personal dan hukum keluarga. Sebagai negara yang penduduknya mayoritas muslim, Tunisia adalah yang paling radikal dalam pembaharuan hukum keluarga Islam. Hal ini dapat dilihat dalam undang-undang yang diberlakukan di negara tersebut yang kemudian disebut Code of Personal Status Tunisia (CPST). Pembaharuan hukum yang terjadi di Tunisia tidak terlepas dari aspek historitas yang melatarbelakanginya. Selain itu, peran pendidikan dan para pejuang nasionalis sebagai pelaku pembaharuan juga ikut menentukan. ${ }^{4}$

\section{Sekilas Tentang Tunisia}

\section{Profil Tunisia}

Nama resmi Negara Republik Tunisia (Republic of Tunisia atau Al Jumhuriyah At Tunisiyah), dengan Ibu kota di Tunis. Bentuk Negara Republik, sistem pemerintahan unitary semi-presidensial, dengan Kepala Negara Presiden dan Kepala Pemerintahan Perdana Menteri. Lagu kebangsaan Houmat El Hima (The Nation's Guardians/Pelindung Tanah Air), dan bahasa yang digunakan bahasa Arab (meskipun bahasa Prancis juga banyak digunakan). Luas wilayah $162.155 \mathrm{~km}^{2}$, terdiri dari 23 provinsi, dengan jumlah penduduk 10.777 .500 jiwa, yang beragama Islam (98\%) (mayoritas Muslim Sunni), Kristen (1\%), Yahudi dan lainnya (1\%), serta suku bangsa Arab (98\%), Eropa (1\%), Yahudi dan lainnya (1\%). ${ }^{5}$

Tunisia terletak di pantai Mediterania Afrika Utara, di tengah antara Samudra Atlantik dan Delta Nil. Pada bagian Barat dan Selatan berbatasan dengan Aljazair (965 km), bagian Utara dan Timur berbatasan dengan Laut Mediterania, dan bagian Selatan dan Tenggara dengan Libya $(459 \mathrm{~km})$. Tunisia terletak di antara garis lintang $30^{\circ}$ dan $38^{\circ} \mathrm{U}$, dan bujur $7^{\circ}$ dan $12^{\circ} \mathrm{T} .{ }^{6}$

4 Khoiruddin Nasution, dkk., Hukum Perkawinan dan Warisan di Dunia Muslim Modern (Yogyakarta: ACAdeMIA, 2012), 43.

5 https://kemlu.go.id/tunis/id/read/profil-negara-republik-tunisia, diakses pada Kamis, 12 November 2020.

${ }^{6}$ https://id.m.wikipedia.org/wiki/Tunisia, diakses pada Kamis, 12 November 2020. 
Undang-Undang Dasar Tunisia disahkan pada tanggal 1 Juni 1959, yang secara tegas dalam pasal 1 menyebutkan bahwa Tunisia adalah Negara yang berdasarkan agama Islam. Bahkan, dalam pasal 38 dinyatakan bahwa presiden Republik Tunisia haruslah seorang muslim. ${ }^{7}$

\section{Sejarah Tunisia}

Pada zaman kuno, Tunisia dihuni oleh Suku Berber. Migrasi kaum Fenisia dimulai pada abad ke-12 SM. dipimpin oleh Carthage. Sebuah saingan Yunani yang hampir dihancurkan Kekaisaran Romawi pada perang punisia kedua, Carthage akhirnya dikalahkan oleh orang Romawi dalam pertempuran carthage pada tahun 149 SM. Kekaisaran Romawi memperkenalkan agama Kristen dan seni arsitektur, termasuk amfiteater El Djem. Tunisia ditaklukkan oleh orang Arab pada abad pertama Hijriah, diikuti oleh Kesultanan Utsmaniyah antara pada tahun 1534. Kesultanan Utsmaniyah menguasai Tunisia selama lebih dari tiga ratus tahun. Semenjak tahun 1574, Tunisia merupakan provinsi otonom pada masa pemerintahan Turki Utsmani. ${ }^{8}$

Pada tahun 1880-an, negara Tunisia menjadi anggota persemakmuran Prancis berdasarkan perjanjian La Marsa. Meskipun mempunyai pemerintahan sendiri, namun kendali pemerintahan berada di bawah kekuasaan Prancis. Hampir semua aspek pemerintahan dikuasai, termasuk sistem admnistrasi dan hukum, serta pada tanggal 12 Mei 1881 Tunisia resmi menjadi wilayah protektorat Prancis. Adanya campur tangan Prancis dalam menentukan kebijakan pemerintah di Tunisia membawa pengaruh positif terhadap kondisi social dan sistem pendidikan juga mengalami kemajuan. Reformasi pendidikan yang dilakukan Prancis pada akhirnya membakar semangat generasi muda Tunisia untuk menentang pemerintahan Prancis.

Nasionalisme bangsa Tunisia dipelopori oleh gerakan dari kalangan elit intelektual, dikenal dengan Young Tunisians, bertujuan mengasimilasi (memadukan) peradaban Prancis sampai

7 Abdullahi A. An-Na'im (ed), Islamic Family Law in a Changing World: A Global Resource Book (London: Zed Books Ltd., 2002), 182.

8 https://id.m.wikipedia.org/wiki/Tunisia, diakses pada Kamis, 12 November 2020. 
akhirnya mereka dapat mengatur negara mereka sendiri. Menggerakkan semangat egalitarisme, gerakan dasar nasionalis ini dilakukan bersama-sama dengan kelompok petani, mahasiswa, feminis, perkumpulan buruh dan semua elemen masyarakat. Tahun 1907 dianggap sebagai langkah awal perjuangan rakyat Tunisia untuk memperoleh kemerdekaan. Dan perjuangan rakyat Tunisia ini akhirnya membuahkan hasil kemerdekaan, pada tanggal 20 Maret 1956 negara Tunisia merdeka secara penuh. ${ }^{9}$

Pada dua periode (kekuasaan Usmani dan protektorat Prancis) telah membawa pengaruh yang sangat besar bagi pembaharuan hukum di Tunisia, diantaranya hukum keluarga. ${ }^{10}$ Sehingga sistem hukum yang dipakai dan diterapkan di Tunisia adalah sistem hukum Islam dan hukum perdata Prancis.

Hukum Islam yang berkembang adalah madzah Hanafi dan Maliki. Madzab Hanafi dikarenakan pengaruh dari kekaisaran Utsmani, namun pada akhirnya madzab Maliki yang memiliki posisi lebih dominan. ${ }^{11}$ Semua hukum keluarga pada masa protektorat Prancis bagi orang Islam diserahkan pada yuridiksi pengadilan syariah yang diketuai oleh hakim-hakim bermadzab Maliki dan Hanafi. Sedangkan bagi mereka yang non-muslim, memakai hukum perdata Prancis.

Pada masa kemerdekaan, Tunisia memiliki pemerintahan sendiri dengan Presiden debagai kepala Negara, sehingga banyak reformasi di segala bidang. Di bawah pimpinan Habib Buorguiba, dengan latar belakang pendidikan Prancis, pemerintah Tunisia mengadakan reformasi terhadap system hukum yang berlaku. Meskipun Habib Buorguibatumbuh dalam struktur Prancis, namun reformasi yang dilakukan tidak sepenuhnya sekuler. ${ }^{12}$ Karena usahnya untuk memerdekakan Tunisia, ditambah reformasinya di bidang hukum dengan terciptanya the Code of Personal Status yang berlaku secara umum, Habib Buorguiba

${ }_{9}$ Abdullahi A. An-Na'im (ed), Islamic Family Law in a Changing World: A Global Resource Book (London: Zed Books Ltd., 2002), 182.

10 Khoiruddin Nasution, dkk., Hukum Perkawinan dan Warisan di Dunia Muslim Modern (Yogyakarta: ACAdeMIA, 2012), 44. 1972), 99.

11 Tahir Mahmood, Family Law Reform in the Muslim Word (Bombay: Tripathi,

12 Konstitusi Tunisia 01 Juni 1959 pasal pertama, menerangkan bahwa Islam adalah agama negara dan bahasa resminya adalah bahasa Arab. 
akhirnya dianggap sebagai the Father of Tunisia. ${ }^{13}$ Pada tahun 2011, terjadi Revolusi Tunisia yang mengakibatkan penggulingan Presiden, yang saat itu dijabat oleh Zine El Abidine Ben Ali. ${ }^{14}$

\section{Perkembangan Hukum Keluarga Di Tunisia}

Reformasi hukum keluarga di Tunisia merupakan bagian dari sebuah produk besar untuk membangun negara modern. Beberapa bulan setelah kemerdekaannya, pemerintah Tunisia langsung memberlakukan hukum keluarga, yang oleh banyak pengamat dianggap cukup maju dalam menginterpretasikan syariat Islam, terutama dalam membela hak-hak perempuan. Namun, bagi kalangan tertentu, hukum keluarga itu dianggap menyalahi bahkan menentang syariat. Aturan-aturan baru tersebut tidak hanya menentang praktek muslim tradisional bahkan menyatakan konfrontasi dengannya, sesuatu yang tidak pernah dilakukan oleh bangsa Prancis.

Reformasi hukum di Tunisia juga terinspirasi oleh adanya reformasi hukum di Mesir, Sudan, dan Syiria. Kenyataan ini memotivasi para ahli hukum Tunisia untuk membuat draft undang-undang. Dalam perkembangannya, selain hukum Islam, negara Tunisia juga mengadopsi prinsip-prinsip hukum Prancis, sehingga output sistem hukum yang dihasilkan merupakan perpaduan sinergis antara prinsip-prinsip hukum Islam (madzab Maliki dan Hanafi) dan prinsip-prinsip hukum sipil Prancis (French civil law). ${ }^{15}$

Draft undang-undang tersebut mendapat respon dari pemerintah, dimana kemudian pemerintah membentuk sebuah komite untuk merancang undnag-undnag secara resmi. Rancangan itu akhirnya diundangkan sesaat setelah Tunisia resmi merdeka (20 Maret 1956). pemerintah Tunisia memberlakukan undangundang hukum keluarga yang disesuaikan dengan perubahanperubahan sosial yang terjadi di Tunisia.

13 Khoiruddin Nasution, dkk., Hukum Perkawinan dan Warisan di Dunia Muslim Modern (Yogyakarta: ACAdeMIA, 2012), 47.

14 https://id.m.wikipedia.org/wiki/Tunisia, diakses pada Kamis, 12 November 2020.

15 Aulia Rahmat, "Kompleksitas Hukum Keluarga Islam di Tunisia”, Jurnal Al Muqaranah Vol. V No. 1 (2016), 33. 
Undang-undang tersebut bernama Majallat al-Ahwal alSyakhshiyah (Code of Personal Status) Nomor 66 tahun 1956, terdiri dari 170 pasal dan terbagi dalam 10 buku, kemudian baru pada tanggal 01 Januari 1957 diberlakukan secara resmi di Tunisia.

Dalam perkembangannya, undang-undang Code of Personal Status Tunisia (CPST) tersebut mengalami kodifikasi dan perubahan (amandemen) beberapa kali, yaitu melalui Undangundang Nomor 70 Tahun 1958, Undang-undang Nomor 77 Tahun 1959, Undang-undang Nomor 41 Tahun 1962, Undang-undang Nomor 1 Tahun 1964, Undang-undang Nomor 17 Tahun 1964, Undang-undang Nomor 49 Tahun 1966 dan Undang-undang Nomor 1 Tahun 1981.16

Ada beberapa alasan pembentukan dan pemberlakuan undang-undang di Tunisia, sebagai berikut: ${ }^{17}$

1. Untuk menghindari pertentangan antara pemikir mazhab Hanafi dan Maliki;

2. Untuk penyatuan pengadilan menjadi pengadilan nasional, sehingga tidak ada lagi perbedaan antara pengadilan agama dan pengadilan negeri;

3. Untuk membentuk undang-undang modern, sebagai referensi para hakim;

4. Untuk menyatukan pandangan masyarakat secara keseluruhan yang diakibatkan adanya perbedaan dari mazhab klasik;

5. Untuk memperkenalkan undang-undang baru yang sesuai dengan tuntutan modernitas.

\section{Hukum Keluarga Islam Di Tunisia}

1. Perkawinan

a. Usia Perkawinan

Laki-laki dan perempuan di Tunisia dapat melakukan perkawinan jika telah berusia minimal 20 tahun. Sedangkan untuk dapat melangsungkan perkawinan, bagi pasangan yang berusia di bawah 20 tahun harus mendapat izin dari wali. Apabila wali tidak memberikan izin, perkara tersebut

16 Aulia Rahmat, "Kompleksitas Hukum Keluarga Islam di Tunisia”, Jurnal Al Muqaranah Vol. V No. 1 (2016), 34.

17 J.N.D. Anderson, "The Tunisian Law of Personal Status", International and Comparative Law Quarterly (1985), 262. 
dapat diputus oleh pengadilan (pasal 5). Akan tetapi, pada tahun 1981, ketentuan pasal ini berubah, bahwa untuk dapat melakukan perkawinan, laki-laki harus berusia 20 tahun dan perempuan harus berusia minimal 17 tahun \{pasal 5 ayat (2)\}. Sehingga bagi mereka yang berusia di bawah ketentuan harus mendapatkan izin dari pengadilan \{pasal 5 (3)\}. Izin tidak dapat diberikan jika tidak ada alasan yang kuat dan keinginan yang jelas dari masing-masing pihak.

Perkawinan di bawah umur tergantung pada izin wali. Jika wali menolak untuk memberikan izin, padahal para pihak telah berkeinginan kuat untuk menikah, perkara dapat diputus oleh pengadilan. Ini merupakan langkah maju jika dilihat dari ketentuan kitab fiqih klasik dari para madzab.

Tidak ada batasan yang jelas mengenai batasan usia menikah dalam kitab-kitab tersebut. Penentuan batasan usia minimal dalam perkawinan juga tidak disebutkan dalam ayat Al Quran secara jelas. Demikian juga halnya dengan hadits Nabi Muhammad SAW yang tidak pernah merincikan batasan usia minimal dalam perkawinan. ${ }^{18}$

Dasar permikiran tidak adanya batasan umur mengenai perkawinan, kiranya sesuai dengan pandangan umat Islam pada masa itu tentang hakikat perkawinan. Menurut mereka, perkawinan itu tidak dilihat dari segi hubungan kelamin, namun lebih dititik-beratkan dalam usaha menciptakan hubungan harmonis, guna tercapai keluarga sakinah mawaddah wa rahmah. ${ }^{19}$

Meskipun secara terang-terangan Al Quran ${ }^{20}$ dan Hadits Nabi tidak memberikan batasan yang jelas, namun dari isyarat secara tidak langsung sudah ada di dalamnya. Ikatan perkawinan akan menimbulkan hak dan kewajiban secara timbal balik. Adanya hak dan kewajiban tersebut

18 Nabi Muhammad SAW menikahi 'Aisyah saat pada usia 6 tahun dan menggaulinya pada usia 9 tahun.

19 Sebagaiamana tujuan perkawinan yang terdapat dalam QS. ar-Ruum (30) ayat 21.

${ }^{20}$ Lihat Q.S. an-Nisa (4) ayat 6, berdasarkan ayat tersebut, dapat dipahami bahwa kebolehan menikah terkait dengan batasan umur, yang dimaksud adalah baligh. 
mengindikasikan bahwa pelakunya diharuskan sudah dewasa. Untuk menetapkan konteks "dewasa" ini, terdapat perbedaan. Terlepas dari konsep yang diberikan oleh para ulama, perbedaan ini juga dipengaruhi oleh perbedaan lingkungan, kebudayaan, tingkat kecerdasan suatu komunitas dan beberapa faktor pendukung lainnya. ${ }^{21}$

b. Perjanjian Perkawinan

Undang-undang Tunisia memberi peluang adanya khiyar al-syart dalam perkawinan. Pasal 11, menjelaskan bahwa jika ada isi perjanjian yang terlanggar, pihak yang dirugikan dapat mengajukan permohonan pembubaran perkawinan. Namun, pembubaran perkawinan tersebut tidak bisa melahirkan hak ganti rugi jika hal tersebut terjadi sebelum perkawinan terlaksana secara sempurna ( $b a^{\prime} d a$ aldukhul).

Dalam literatur fiqih tidak memberikan pembahasan khusus terhadap perjanjian perkawinan. Pembahasan fiqih cenderung pada persyaratan dalam perkawinan. Perjanjian merupakan bagian yang terpisah dari akad perkawinan itu sendiri, apabila perjanjian perkawinan dilalaikan oleh salah satu pihak, tidak berarti akad perkawinan batal. Pada dasarnya, kedua belah pihak wajib menepati janji perkawinan kendatipun materinya tidak dituliskan dalam akad nikah. Sehingga kealpaan salah satu pihak untuk menunaikannya, baik secara menyeluruh ataupun prsial, menyebabkan adanya tuntutan perceraian. ${ }^{22}$ Namun, pihak yang dirugikan mempunyai hak untuk mengajukan pembatalan perkawinan. ${ }^{23}$

\section{c. Poligami}

Pasal 18 menyatakan bahwa beristri lebih dari satu orang (poligami) adalah perbuatan yang dilarang. Demikian 2007), 68 .

${ }^{21}$ Amir Syarifuddin, Hukum Perkawinan Islam di Indonesia (Jakarta: Kencana,

22 Muhammad Shahrur, Metodologi Figh Islam Kontemporer (Yogyakarta: eLSAQ Press, 2004), 439.

${ }^{23}$ Amir Syarifuddin, Hukum Perkawinan Islam di Indonesia (Jakarta: Kencana, 2007), 146. 
pula, dalam Undang-undang ini secara tegas menerangkan apabila seoarang laki-laki yang telah menikah dan perkawinannya belum putus secara hukum, kemudian menikah lagi, maka diancam hukuman penjara satu tahun atau denda setinggi-tingginya 240.000 franc. $^{24}$

Dasar larangan poligami yang dipergunakan oleh pemerintah Tunisia menurut John L. Esposito, adalah: pertama, bahwa poligami, sebagaimana perbudakan, merupakan institusi yang tidak dapat diterima mayoritas umat manusia di mana pun; dan kedua, Ideal Al Quran tentang perkawinan adalah monogami. ${ }^{25}$

Menurut Muhammad Abduh, izin poligami sebagaimana yang dijelaskan dalam Quran surat an-Nisa (4) ayat 3 telah dibatasi dengan penjelasan dalam Quran itu sendiri, surat an-Nisa (4) ayat 129. Ideal sebuah perkawinan berdasarkan Al Quran adalah menggunakan asas monogami. Lebih dari itu, syarat yang diajukan kepada suami agar sanggup untuk berlaku adil terhadap para istri adalah suatu kondisi yang sangat sulit, bahkan tidak mungkin dapat terealisasikan sepenuhnya. ${ }^{26}$

Alasan yang dikemukakan Tunisia melarang poligami adalah: pertama, bahwa institusi budak dan poligami hanya boleh pada masa perkembangan atau masa transisi umat Islam, tetapi dilarang pada masa perkembangan atau masyarakat berbudaya; dan kedua, bahwa syarat mutlak bolehnya poligami adalah kemampuan berlaku adil pada istri, sementara fakta sejarah membuktikan hanya Nabi SAW yang mampu berlaku adil terhadap istri-istrinya. ${ }^{27}$

Apa yang terdapat dalam Quran harus ditafsirkan, tidak hanya sekedar sebuah desakan moral, namun merupakan preseden kondisi hukum bagi poligami, dalam

24 Atho' Mudzar dan Khoiruddin Nasution, Hukum Keluarga di Dunia Islam Modern: Studi Perbandingan dan Keberanjakan UU Modern dari Kitab-kitab Fiqih (Jakarta: Ciputat Press, 2003), 90.

${ }^{25}$ John L. Esposito, Women in Muslim Family Law (New York: Syracus University Preess, 1982), 92.

${ }^{26}$ John L. Esposito, Women in Muslim Family Law (New York: Syracus University Preess, 1982), 93.

27 Aulia Rahmat, "Kompleksitas Hukum Keluarga Islam di Tunisia”, Jurnal Al Muqaranah Vol. V No. 1 (2016), 40. 
artian bahwa tidak satupun perkawinan kedua dapat diizinkan kecuali dan sampai terbukti dapat berlaku sama (egaliter) di mana para istri diperlakukan dengan adil. Namun melihat kondisi sosial dan ekonomi modern sepertinya sikap adil merupakan suatu hal yang mustahil, sehingga poligami tidak dapat terpenuhi dan dilarang.

d. Perkawinan Yang Tidak Sah

Perkawinan yang dipandang tidak sah (fasid, invalid) oleh Undang-undang Hukum keluarga Tunisia:

1) Perkawinan yang bertentangan dengan dasar-dasar perkawinan (pasal 21);

2) Perkawinan yang dilakukan tanpa ada izin dari salah satu pihak, baik suami atau istri (pasal 3);

3) Perkawinan yang dilakukan sebelum usia pubertas atau diantara pasangan mempelai terdapat halangan hukum lainnya (pasal 5);

4) Perkawinan yang di dalamnya terdapat halangan perkawinan (pasal 15-17);

5) Perkawinan yang dilangsungkan oleh seorang lakilaki dengan seorang perempuan yang masih dalam masa iddah (pasal 20).

Perkawinan yang tidak sah dapat segera dibatalkan. Perkawinan yang berlangsung sempurna ( $\left.b a^{\prime} d a d u k h u l\right)$ maka istri berhak atas mahar dan wajib menjalani masa iddah. Namun apabila qobla dukhul, maka istri berhak menerima mahar musamma. Status anak yang lahir dapat disandarkan nasabnya pada suami, tapi tidak ada hak untuk saling mewarisi (pasal 22). ${ }^{28}$

\section{Perceraian}

Dalam Undang-undang Hukum Keluarga Tunisia, perceraian yang diucapkan/dilakukan secara sepihak tidak mengakibatkan jatuhnya talak. Perceraian yang sah dan

28 Atho' Mudzar dan Khoiruddin Nasution, Hukum Keluarga di Dunia Islam Modern: Studi Perbandingan dan Keberanjakan UU Modern dari Kitab-kitab Fiqih (Jakarta: Ciputat Press, 2003), 90. 
berkekuatan hukum apabila dilakukan dan diputuskan oleh pengadilan.

Pengadilan dapat menjatuhkan putusan cerai jika diminta oleh istri dengan alasan suami telah gagal dalam memenuhi nafkahnya (pasal 31 dan 40), karena kedua belah pihak telah sepakat untuk melakukan perceraian. Pengadilan juga dapat memutuskan perkawinan yang diajukan sepihak, dengan ketentuan pihak tersebut wajib membayar ganti rugi kepada pihak lainnya. Putusan perceraian hanya akan diberikan, dalam segala kondisi apabila upaya damai yang telah diusahakan oleh para pihak (suami-istri) gagal dicapai (pasal 32). ${ }^{29}$

Regulasi ini menunjukkan keseriusan pemerintahan Tunisia dalam mengakomodir dan melindungi hak-hak perempuan. Terlihat juga betapa pentingnya untuk mencatatkan perkawinan yang bukan hanya sekedar formalitas belaka. Selain berfungsi sebagai tertib administrasi dan perlindungan hukum bagi warga Negara, adanya asas legalitas ini juga mempermudah pihak-pihak terkait dalam melakukan pengawasan dalam pelaksanaan undang-undang. ${ }^{30}$

a. Talak Tiga

Pasal 19 menegaskan bahwa seorang laki-laki dilarang merujuk mantan istrinya yang telah dijatuhkan ditalak tiga (talak bain kubro). Sebelumnya, pasal 14 menyebutkan bahwa talak tiga menjadi halaangan untuk menikah yang bersifat permanen. ${ }^{31}$ Ketentuan dalam pasal ini sesuai dengan pendapat-pendapat yang dijelaskan dalam kitab-kitab fiqih.

b. Nafkah Bagi Istri

${ }^{29}$ Khoiruddin Nasution, dkk., Hukum Perkawinan dan Warisan di Dunia Muslim Modern (Yogyakarta: ACAdeMIA, 2012), 52.

30 Muhammad Amin Suma, Hukum Keluarga Islam di Dunia Islam (Jakarta: Rajawali Grafindo, 2005), 188.

31 Tahir Mahmood, Family Law Reform in the Muslim Word (Bombay: Tripathi, 1972), 103. 
Undang-undang Hukum Keluarga Tunisia menggunakan prinsip-prinsip mazhab Maliki dalam hal nafkah istri. Hal ini telah diatur secara rinci dalam pasal 37-42. Pasal 41 menyatakan bahwa istri diizinkan membelanjakan harta pribadinya yang digunakan sebagai biaya hidup dengan maksud untuk dimintakan ganti rugi dari suami. Besarnya jumlah nafkah, tergantung pada kemampuan suami dan status istri, serta biaya hidup yang wajar (pasal 52). Lebih menariknya, suami yang menghindar dari kewajiban memberi nafkah atau kompensasi selama 1 bulan dapat dikenakan hukuman penjara 3-12 bulan dan denda antara 100-1000 dinar (pasal 53). ${ }^{32}$

Kewajiban suami untuk memberikan nafkah kepada istri yang berlaku dalam fiqh didasarkan kepada adanya pemisahan harta antara suami dan istri. Fikih mazhab Maliki yang banyak dijadikan rujukan dalam regulasi ini menyatakan bahwa nafkah wajib dibayar suami jika telah terjadi dukhul dan suami telah baligh. Pandangan ini berbeda dengan pendapat Abu Hanifah dan salah satu pendapat Imam Syafi'i yang tidak mensyaratkan agar suami harus baligh. ${ }^{33}$

c. Pemeliharaan Anak

Pasal 54-57 secara rinci telah mengatur hak dan kewajiban orang tua dan para wali terhadap pemeliharaan anak (hadhanah). Ketentuan tersebut secara umum bersumber dari prinsip-prinsip yang dikembangkan dalam mazhab Maliki. Apabila seorang laki-laki mentalak istri, maka pemeliharaan anak adalah hak ibu, dengan alasan sorang ibu lebih besar kasih sayangnya dan memahami kemashlahatan serta kebutuhan anak dibanding seorang ayah atau keluarga lainnya. Formulasi fiqh juga menyatakan bahwa hak hadhanah ibu menjadi terputus apabila ibu

32 Aulia Rahmat, "Kompleksitas Hukum Keluarga Islam di Tunisia”, Jurnal Al Muqaranah Vol. V No. 1 (2016), 45.

33 Aulia Rahmat, "Kompleksitas Hukum Keluarga Islam di Tunisia", Jurnal Al Muqaranah Vol. V No. 1 (2016), 45. 
melangsungkan perkawinan, disebabkan karena adanya dugaan bahwa hal tersebut bisa membuat ibu menjadi lalai dalam mengurusi anak sehingga anak tidak bisa hidup dengan tenang dan sejahtera.

Pasal 67 menjelaskan bahwa pengadilan berhak memutuskan batas waktu pemeliharaan anak dengan mempertimbangkan kondisi anak yang bersangkutan sepenuhnya. Formulasi fiqh menyatakan bahwa batas berakhirnya hadhanah adalah jika anak laki-laki telah mencapai batas usia baligh dan anak perempuan telah menikah. Sedikit berbeda dengan pendapat Imam Syafi'i yang menyatakan bahwa batas hadhanah anak perempuan adalah ketika ia juga sudah baligh. ${ }^{34}$

3. Kewarisan

Hukum waris di Tunisia secara umum hanya melakukan kodifikasi dari ketentuan-ketentuan waris yang dimuat dalam kitab fiqih imam Maliki. Akan tetapi dalam beberapa hal juga diadopsi dari pendapat dari mazhab lain di luar mazhab Maliki.

Antara lain adalah dalam pasal 88 yang menyatakan bahwa seorang ahli waris yang dengan sengaja menyebabkan kematian pewaris, baik sebagai pelaku utama atau hanya sebagai pelaku pendukung, atau mengungkapkan kesaksian palsu terhadap kematian pewaris, maka ia tidak berhak mendapatkan warisan dari pewaris yang meninggal. Lainnya, dalam pasal 143 (a) menyatakan bahwa anak perempuan dan anaknya dapat menerima asabah dalam warisan, walaupun ada ahli waris dari pihak laki-laki seperti saudara laki-laki dan paman..$^{35}$

4. Wasiat

a. Perbedaan Agama dan Kewarganegaraan

Regulasi berkaitan dengan wasiat yang paling menonjol adalah adanya legitimasi wasiat yang terjadi

34 Aulia Rahmat, "Kompleksitas Hukum Keluarga Islam di Tunisia”, Jurnal Al Muqaranah Vol. V No. 1 (2016), 46.

35 Khoiruddin Nasution, dkk., Hukum Perkawinan dan Warisan di Dunia Muslim Modern (Yogyakarta: ACAdeMIA, 2012), 53. 
antara dua orang yang berbeda agama dan antara dua orang yang berbeda warga Negara (pasal 174-175). Mayoritas doktrin dalam fiqh klasik menyebutkan bahwa tidak ada kemungkinan untuk saling memberikan wasiat di antara muslim dan non muslim. Dalam wasiat tidak memberikan batasan bagian tertentu yang harus diikuti oleh pewasiat, prosentase pemberian wasiat adalah hak mutlak pewasiat yang kadarnya berdasarkan pertimbangannya sendiri.

Pasal 176 menjelaskan bahwa bukti yang menunjukkan bahwa telah terjadi wasiat adalah adanya bukti otentik tertulis yang tertanggal dan ditandatangani oleh pihak yang berwasiat, sehingga keberadaan bukti yang disampaikan melalui ucapan/oral tidak dianggap sebagai bukti dalam wasiat. Ketentuan ini memang berbeda dengan pendapat-pendapat ulama zaman klasik, yang menyatakan bahwa tidak ada redaksi yang baku untuk berwasiat. Wasiat dianggap sah diucapkan dengan redaksi yang bagaimanapun, yang bisa dianggap menyatakan pemberian hak kepemilikan secara sukarela setelah wafat. ${ }^{36}$

Dalam Undang-undang Hukum Keluarga Tunisia tidak mengakui wasiat yang maksudnya sebagian dari warisan. Ketentuan ini berbeda dengan hukum yang berlaku di Mesir dan Sudan. ${ }^{37}$

b. Wasiat Wajibah

Ketentuan mengenai wasiat wajibah telah diperkenalkan pada Undang-undang Mesir tahun 1946, yang kemudian diikuti oleh Syiria dan Tunisia. Undangundang Hukum Keluarga Tunisia menyatakan bahwa ketentuan mengenai wasiat wajibah hanya diperuntukkan bagi cucu yatim dari generasi pertama, baik laki-laki maupun perempuan, dengan perbandingan

${ }^{36}$ Aulia Rahmat, "Kompleksitas Hukum Keluarga Islam di Tunisia”, Jurnal Al Muqaranah Vol. V No. 1 (2016), 49.

37 Tahir Mahmood, Family Law Reform in The Muslim World (Bombay: Tripathi, 1972), 105. 
5. Adopsi

Adopsi atau anak angkat diperkenalkan dalam hukum keluarga Tunisia melalui Undang-undang Perwalian dan Adopsi tahun 1958. 39 Undang-undang ini terdiri dari 60 pasal yang dibagi dalam 3 bab, masing-masing mengenai perwalian, kafalah dan anak angkat atau adopsi. Dalam kurun waktu satu tahun kemudian, ketentuan mengenai anak angkat diamademen. Tata cara, ketentuan dan syarat pengangkatan anak itu secara detail disebutkan dalam pasal 9-16 Undang-undang tersebut. ${ }^{40}$

Pihak yang diperbolehkan melakukan pengangkatan anak adalah laki-laki dan perempuan, dengan syarat harus sudah dewasa, telah menikah dan mempunyai hak sipil secara penuh, berkarakter moral yang baik, sehat jasmani maupun rohani dan secara finansial mampu memenuhi kebutuhan seorang anak yang diangkat. Pada pasal 9 dijelaskan bahwa pengadilan juga bisa memberikan izin kepada seorang janda atau duda (karena kematian pasangan), atau orang yang telah bercerai untuk mengangkat seorang anak. Diwajibkan bagi orang-orang tersebut untuk memenuhi semua aspek adopsi yang diusulkan sebagai keperluan anak yang hendak diadopsi, termasuk izin dari pasangan (suami/istri) disyaratkan untuk menentukan sah atau tidaknya praktek adopsi yang dilakukan oleh seseorang (pasal 11).

Perbedaan atau selisih usia antara pihak yang akan melakukan adopsi dengan anak yang hendak diadopsi minimal 15 tahun. Seorang warga negara Tunisia diperbolehkan melakukan adopsi terhadap seorang anak yang bukan dari warga negara Tunisia (pasal 10).

38 Khoiruddin Nasution, Status Wanita di Asia Tenggara: Studi terhadap Perundangundangan Perkawinan Muslim Kontemporer di Indonesia dan Malaysia (Jakarta: INIS, 2002), 122.

39 Tahir Mahmood, Personal Law in Islamic Countries: History, Text and Comparative Analysis (New Delhi: Academy of Law dan Religion, 1987), 154.

40 Tahir Mahmood, Personal Law in Islamic Countries: History, Text and Comparative Analysis (New Delhi: Academy of Law dan Religion, 1987), 164-166. 
Praktek adopsi berakibat diperolehnya nama baru (nasab) bagi si anak dari orang tua angkat, nama asli juga bisa dirubah. Jika diinginkan oleh oleh pihak yang melakukan adopsi, maka nama baru anak yang diadopsi itu bisa dicatatkan pada surat adopsi tersebut (pasal 14). Anak angkat memperoleh hak dan kewajiban yang sama sebagaimana layaknya anak kandung, demikian juga halnya dengan orang tua angkatnya. Akan tetapi, bagi anak tersebut masih berlaku larangan kawin dengan keluarga kandungnya (pasal 15).

Pengadilan melalui jaksa penuntut umum, bisa mengambil alih anak angkat dari orang tua angkatnya apabila terjadi kesalahan dan kelalaian dalam pemenuhan kewajiban, sehingga haknya akan dipindahkan kepada orang lain. Hal ini dilakukan demi menjaga kepentingan anak tersebut (pasal 16).

\section{Kesimpulan}

Proses perumusan dan penataan hukum keluarga Islam di Tunisia, tidak hanya sekedar upaya kodifikasi (pembukuaan) fikih mazhab Maliki maupun Hanafi serta adanya pengaruh Prancis, akan tetapi juga melakukan langkah-langkah progresif dan revolusioner dalam upaya melakukan legalisasi dan regulatory dalam bidang hukum, khususnya Hukum Keluarga Islam, dibuktikan dengan lahirnya Majallat al-Ahwal al-Syakhshiyah atau Code of Personal Status Tunisia (CPST).

Sikap negara Tunisia terhadap pembaharuan hukum secara umum masuk dalam kelompok negara yang melakukan pembaharuan hukum secara demokrat untuk disesuaikan dengan tuntutan dan perkembangan zaman sesuai dengan konteks kontemporer. Sifat metode yang digunakan dalam pembaharuan hukum keluarga tetap merujuk pada konsep fiqih konvensional (intra doctrinal reform) dengan disinergikan dengan warisan hukum Prancis guna melakukan reinterpretasi pada nash (ekstra doctrinal reform).

Reformasi hukum yang dilakukan Tunisia, tidak bermaksud untuk melakukan penyimpangan dan meninggalkan prinsipprinsip Hukum Islam, akan tetapi lebih disebabkan keinginan pemerintah untuk menjamin kesejahteraan, kedamaian, dan 
kemaslahatan bangsa dan rakyat Tunisia. Dengan pembaharuan hukum keluarga Tunisia, hal ini menunjukkan bahwa tujuan pembaharuan hukum keluarga tersebut menitikberatkan pertimbangan rasional dan kontekstual untuk menciptakan masyarakat modern. 


\section{Daftar Rujukan}

Anderson, J.N.D., The Tunisian Law of Personal Status, International and Comparative Law Quarterly, 1985.

An-Na'im, Abdullahi A. (ed), Islamic Family Law in a Changing World: A Global Resource Book, London: Zed Books Ltd., 2002.

Bancia, Ratih Lusiani "Hukum Keluarga Islam di Tunisia”, Jurnal: Penelitian Medan Agama Vol. 9 No. 2, 2018.

Esposito, John L., Women in Muslim Family Law, New York: Syracus University Preess, 1982.

https://id.m.wikipedia.org/wiki/Tunisia, diakses pada Kamis, 12 November 2020.

https://kemlu.go.id/tunis/id/read/profil-negara-republik-tunisia, diakses pada Kamis, 12 November 2020.

Mahmood, Tahir, Family Law Reform in the Muslim Word, Bombay: Tripathi, 1972.

Mahmood, Tahir, Personal Law in Islamic Countries: History, Text and Comparative Analysis, New Delhi: Academy of Law dan Religion, 1987.

Mudzar, Atho' dan Khoiruddin Nasution, Hukum Keluarga di Dunia Islam Modern: Studi Perbandingan dan Keberanjakan UU Modern dari Kitab-kitab Fiqih, Jakarta: Ciputat Press, 2003.

Nasution, Khoiruddin, Status Wanita di Asia Tenggara: Studi terhadap Perundang-undangan Perkawinan Muslim Kontemporer di Indonesia dan Malaysia, Jakarta: INIS, 2002.

Nasution, Khoiruddin, dkk., Hukum Perkawinan dan Warisan di Dunia Muslim Modern, Yogyakarta: ACAdeMIA, 2012.

Rahmat, Aulia "Kompleksitas Hukum Keluarga Islam di Tunisia", Jurnal Al Muqaranah Vol. V No. 1, 2016.

Ranuwijaya, Utang dan Ade Husna "Pembaharuan Hukum Keluarga Islam di Indonesia dan Tunisia (Studi Implementasi Ketentuan)", Jurnal Kajian Keislaman: Saintifika Islamica Vol. 3 No. 1, Januari-Juni 2016.

Shahrur, Muhammad, Metodologi Figh Islam Kontemporer, Yogyakarta: eLSAQ Press, 2004.

Suma, Muhammad Amin, Hukum Keluarga Islam di Dunia Islam, Jakarta: Raja Grafindo Persada, 2004.

Syarifuddin, Amir, Hukum Perkawinan Islam di Indonesia, Jakarta: Kencana, 2007. 